\title{
SUPPORTING STATISTICAL LITERACY WITH ICT-BASED TEACHING SCENARIO
}

\author{
Ourania Rizou $^{1}$, Aikaterini Klonari ${ }^{2}$ and Dimitrios Kavroudakis ${ }^{3}$ \\ ${ }^{1}$ University of the Aegean, Department of Geography, University Hill, 81100 Mytilene \\ ${ }^{2}$ Emeritus Professor, University of the Aegean, Department of Geography, \\ University Hill, 81100 Mytilene \\ ${ }^{3}$ Assistant Professor, University of the Aegean, Department of Geography, \\ University Hill, 81100 Mytilene
}

\begin{abstract}
Statistical literacy is gaining recognition as something that people should have in order to function fully in 21 st century's society. On a daily basis an enormous volume of data are available through the Web; making the best of it demands possession of a high level of statistical training. In this paper we present a new technology-augmented teaching scenario, implemented in a way that it may be fully utilized by both teachers and students. Using the features of the web-based platform statistics4school - a free online educational tool for statistical analysis in the Greek language - it paths a teaching method that can be readily facilitated in the classroom. The presented worksheet allows students to have an interdisciplinary approach and be actively involved in the learning process through the exploratory teaching method. In this manner we maintain they will be able to correctly comprehend the goals of the teaching scenario, as they progressively develop their statistical, optical, and digital literacy.
\end{abstract}

\section{KEYWORDS}

Statistical literacy, Geospatial literacy, ICT literacy, Teaching Scenario.

\section{INTRODUCTION}

The last two years were undoubtedly marked by the global spread of the Covid-19 virus, to such an extent that it has since become an integral part of our daily routine. This pandemic has tipped the scales on our personal and socio-economical lives, leaving tragedy in the aftermath in certain cases.

Amidst this, people around the world were -still are, in fact- bombarded on a daily basis with reports rich in statistical data and information. On one hand, this format of news broadcast offers a rationalized background for critical decision making [1] while on the other hand it may also lead to erroneous interpretation, which in turn paves the way to deception and misconception [2, $3,4]$.

As we stand on the apex of the 4th Industrial Revolution, our societies are commonly characterized by high rates of growth and technological improvements - primarily evident in the availability of digital tools (cloud services, nanotechnology, etc.)- as well as (by) the enormous volume of data at hand - leading to the coining of the term Big Data, which get circulated and recycled via the Internet $[5,6,7]$. The usability of all these data -literally in every activity of our daily life- establishes the need for a modern citizen to possess a high degree of respective literacy [8] alongside with their statistical training as a priority. 
Literacy is traditionally known to be tied to the concepts of reading and writing and it plays a major part to the demographic and socio-economic life of any community, being key to human evolution, both socially and vocationally [9]. In the past decades, literacy has been seen in the company of an increasing number of adjectives such as statistical, visual, digital [8], geospatial [10], and data [11]. This demonstrates the need for simultaneous training of individuals at the earliest possible time in multiple forms of literacy.

Statistics has found numerous applications - as a scientific field, a tool, or bare knowledge. For this reason alone they started teaching it very early on in schools (kindergarten even, on some occasions), aiming to help tomorrow's citizens develop positive attitudes and constructive behaviours in the highest degree possible $[12,13,14,15]$. It is believed that only then will they possess the skill to comprehend and put to good use the data in their disposal, to their personal benefit and not the other way around. This process starts at school and their training as pupils even [11].

Statistical literacy is based upon statistical data and information and is interwoven with statistical training [16]. However, not everyone possesses the basic level of know-how to understand and, more importantly, interpret statistical information [17]. Additionally, the transition from the education model of introducing formulas and calculations to the model of understanding the framework and principles that rule Statistics, is a leap towards statistical thinking and statistical reasoning. It is not far from the truth then to argue that Statistics is not just a gnostic subject but a science with revolves around three axes: statistical literacy, statistical reasoning and statistical thinking [18].

Within the boundaries of the education process many an attempt have been made to improve the respective skillset of students, as statistical and geospatial literacy combined lead to the evolution of critical thinking $[6,19,20,10]$. Spatial thinking is a common cornerstone in acquiring other skillsets, such as visual and digital literacy as well as being able to "reason about earth systems and interconnections" - an ability typically called geoliteracy [10]. The impact of these skillsets cannot be overestimated as they enable one read messages in shapes and images, interactive objects and 3D maps etc., typical information conveyors around modern work environments, classrooms, travel schedules, crisis management systems. Moreover, the rapid spread of Information and Communications Technology (ICT) led to significant changes in various fields, with education being but one of them [21].

School, being one of the primary pillars of human evolution is also the earliest methodical training stage, supplying tomorrow's citizens with the tools necessary for their impeding journey. Infusing teaching sessions with multimedia presentation methods and multimodal scenarios, through STE(A)M activities (Science, Technology, Engineering, Art and Math), leads to higher degree of student participation and training unto a multitude of literacies simultaneously. Curriculum reform of Mathematics is escorted by the incorporation of Statistics in education [22, $23,24,25]$. At the same time, Geography teaching seems perpetually stagnant to the 'tried and tested' methods of reading legends and labels on atlases when it could also benefit from ICTenhanced teaching methods. Modern students are already more than acclimated to using virtual globes (like Google Earth) and intelligent route discovery applications on their smartphones; introducing Geographical Information Systems (GIS) in the classroom is not only natural, but also required. It stands to reason then, that teachers ought to cross over from the traditional education model to a more contemporary one. The point where Statistics crosses paths with Geography and ICT becomes a game changer when a student takes real-world data (raw or processed), acquires proper geospatial and statistical training and develops the ability to critically view and assess a situation, headed for a more viable future [18, 12, 26, 27]. 


\section{TheOretiCAL BACKground}

\subsection{Big Data and Data Literacy}

The times we live in has been called the Era of Big Data, whose main characteristics include volume, speed, discrimination, integrity and value [7]. We get deluged by technological innovations applied to our daily lives, in areas such as health, education, sciences and transportation $[11,28]$. There are data employed by companies or service providers to help them create the profile of citizen-users in order to steer or manipulate them towards such ends as financial profit, oniomania (i.e. the obsessive and uncontrollable urge to buy things), etc. [11]. Then again, there are data originating from satellites and other GIS that help create modern day 'atlases' and smart navigation systems. Overall data availability has increased nowadays mainly due to the use of modern computational sources (such as new digital sensors) as well as availability of modern Personal Computer (PC) and relevant technologies.

The term Data Literacy first appeared at the turn of the 21st century but only recently has it been used systematically [1]. It relates to the ability of a person to read, analyse, create, comprehend and communicate data in the form of information [29, 30, 31]. More and more does it show up in recent bibliography as it attempts to emphasize the need to have modern day citizens skilled with the ability to understand and utilize data to their benefit. This attitude finds its roots at school and one's early training there $[32,11,31]$. It borrows from a multitude of frameworks, disciplines and methods rooted in Statistics, Information, Technology \& Education (ITE), Cartography, Geography, Mathematics and Computer Science [1], to name but an indicative few. One could argue that it is equally important to be able to comprehend statistical measures as it is reading information off an interactive map or using a Global Positioning System (GPS) to find the optimal route to your destination. One way or another, depending on the situation at hand, all these situations can lead to making timely, crucial and educated decisions that can affect people's lives, short or long term, or an entire system's sustainability and operation.

More often than not, we find lately 'alternative' news substituting facts and emotions weighing more than actual events; misinformation has intruded every level of our individual and social life, leading to deleterious effects for the person or society itself. Sadly, only 1 out of 15 people are able to tell the difference between reality and fiction, fact and opinion [33, 31]. This is why Statistical and Data Literacy should evolve hand in hand, as they share a strong interaction [13, $1]$.

\subsection{Statistical Literacy, Statistical Thinking and Statistical Reasoning}

Statistical literacy first appeared in bibliographic references at the end of 1970 [28]. In the decades that followed it kept evolving and showing up under numerous and varying definitions $[13,34,35,36]$. That said, we consider the following model to best describe its meaning (Figure $1)$ : 
International Journal of Education (IJE) Vol.9, No.4, December 2021

\begin{tabular}{|c|c|}
\hline Knowledge elements & Dispositional elements \\
\hline $\begin{array}{c}\text { Literacy skills } \\
\text { Statistical knowledge } \\
\text { Context knowledge } \\
\text { Critical questions }\end{array}$ & $\begin{array}{c}\text { Beliefs and Attitudes } \\
\text { Critical stance }\end{array}$ \\
\hline \multicolumn{2}{|c|}{} \\
\hline
\end{tabular}

Figure 1: A model of statistical literacy (Gal, 2019)

This model makes it obvious that statistical literacy is a lot more than training in the use of formulas and tools to apply in statistical studies; it extends to the development of skills and attitudes that are valuable assets for a modern citizen [28, 37].

Instructors that either teach or use Statistics, or practice both, in the course of the educating process should always aim to develop and cultivate in their students statistical literacy alongside statistical reasoning and statistical thinking [25], as this triplet is inextricably interlinked.

Statistical literacy is hard to define, as we already mentioned. One measure of its complicacy is the number of definitions that have been offered in various bibliographic references. Citizens of today need not only develop generic skills and literacies but more importantly to achieve high levels of statistical and critical thinking [22, 14]. When this process is performed in a properly structured environment, built around a positive approach to learning and based on the right pedagogical methods, it bequeaths future citizens with all the attributes necessary to formulate viable attitudes towards any issue they may have to deal with [38]. Moreover, it has been offered that statistical literacy can be seen as the natural extension of schooling [39] since according to Guidelines for Assessment and Instruction in Statistics Education (GAISE) College Report of American Statistical Association (ASA) Revision Committee, school is commissioned to develop literacies in tomorrow's citizens [40]. Taking into account the amount and variety of exercised teaching methods, the offered knowledge span, the level of understanding of the learning needs of pupils and students, school is best suited to arm educators with the tools needed for the task.

Based on the fact that Statistics have been a part of the Curriculum of mandatory training degrees in many countries for some years now, one would expect that teachers and students possess a high level of statistical education; on the contrary, this ratio is rather low [34, 13, 24]. This is mostly due to the simplistic and purely computational/mathematical presentation of very few, headline terms of Statistics - as dictated by the Curriculum, of course. In addition to this, its inherent complexity, rich in semantic and mathematic concepts [26, 6], along with the absence of required teaching skills and a noted lack of self-confidence on the educators' part regarding its use and presentation in the classroom [22, 32], instill scepticism and reluctance in them. In turn, this chain unmistakably leads school graduates to acquiring a poor level of statistical literature; these people can potentially be fooled or misled when presented with statistical information [41, $33,4])$. The controversy over the Covid-19 pandemic's handling and effects made the level of statistical illiteracy even clearer to see, as well as ways that this can lead to crucial mistakes in judgment calls, bringing about tragic reverberations on the population, globally [1]. It becomes obvious then that it is imperative that educators are the first that need to acquire proper training for the task, one tailored to fit all aspects of taught Statistics, before they set out to pass it on inside their classrooms [42]. 
Statistical thinking is infallibly tied to problem solving as it lays the foundations for thorough research and analysis, beyond calculations and formulas. Citizens of a younger age, primarily, frequently demonstrate some difficulty in solving problems in their daily activities; they find it hard if not impossible to apply theory into practice as they lack the required skills and knowledge to do so. It has become evident that a broad participation of students in all the steps involved in the process of solving a statistical problem (data collection, query creation, response analysis and coding, interpretation, etc.) will assist them in this direction [23, 43]. In this manner students develop their critical thinking as they combine innovative tools and scientific fields in creative ways [44]. Research has shown that students who possess even basic skills in Mathematics demonstrate a higher growth of statistical thinking; as a matter of fact, their level of statistical thinking is dependent on their level of understanding math [45].

\subsection{Statistics in Education}

Arguments on a wide range of topics today are built around and based on the use and interpretation of data sets, regardless of their origin and means of distribution - the Web, the media or any of the social networks [7, 46, 47]. It is not uncommon, however, to observe these turn into a wildfire of disinformation which, when paired with ignorance on the recipient's side, form a considerable threat on our society. This effect, when projected to the proportions of our consistently multifarious social systems, makes the need to have thinking citizens participate in decision making stand out as a vital requirement - be it on a local, national or international level $[41,48]$.

Statistics is called upon to close the gaps, serving not solely as a science but also as a tool [39]. It pertains to the collection, organization, encoding, presentation and interpretation of data. It is divided into two main types, Descriptive and Inductive, with the former being more dominant as it relates to formulas and calculations [6, 49]. Statistics and Mathematics can often be perceived like twin siblings, as we observe the similarities they share. It is wrong to consider Statistics a part of Mathematics. They are separate concepts that coexist due to math being necessary for the attainment of statistical literacy [6]. The statistical and mathematical ways of thinking are not completely facsimile. The main difference between them is found in the divergent way of construction; the first is inductive-probabilistic while the mathematical way of thinking is deductive- deterministic [2]. However, both share similarities regarding the means used for approaching the solution of a problem met in our daily life [2]. From national to global level, the trend in education is to reform the Mathematics Curriculums (MC) in such a way that they incorporate Statistics [50, 51, 52, 38]. Statistical literacy, statistical reasoning and statistical thinking are the three axes around which Statistics orbits $[18,38,28]$. In the following figures (Figure 2 and Figure 3) one can clearly see the interconnectivity between the three axes, with the latter considered the more accurate presently [18].

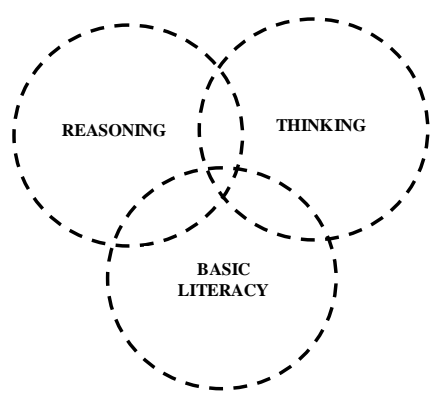

Figure 2: Independent domains with some interaction (Campos \& Perin, 2020)

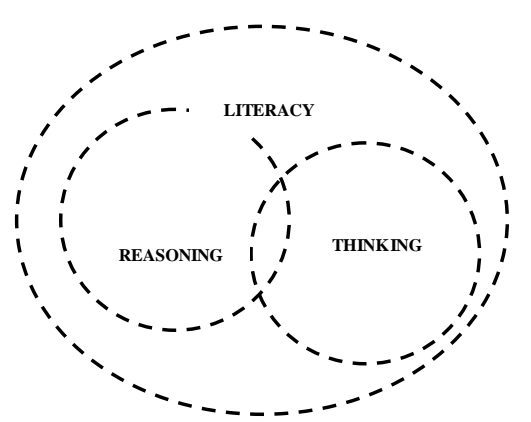

Figure 3: Reasoning and thinking inside the literacy (Campos \& Perin, 2020) 
Modern day practices have highlighted the importance and necessity to have civilians possess high levels of statistical training $[36,6,16]$. Sadly, research shows that students today are more involved into 'learning' Statistics than understanding and interpreting its workings [53]. Furthermore, they are generally biased against it as they have come to believe as nothing more than formulas and calculations. However, if we were to associate Statistics with real-life data and help it break free from the strict boundaries of Mathematics, we can surely reap benefits [38].

\subsection{Geography and Statistics}

Cartography is one of the oldest disciplines in human history. From the maps of ancient times, charting courses of commerce, to the first extant terrestrial globe portraying our world in glorious, lifelike and accurate spherical representation, geography has travelled a long and meticulous journey. The emergence of ICT and the more recent bloom of GPS ushered mapmaking into the digital era. Maps of today are fully fledged multimedia and multimodal applications featuring a plethora of meta-data, literally at the palm of one's hand, as they are available in a number of varied platforms and devices - palmtops/personal digital assistants (PDAs), personal computers, smartphones, etc. $[10,54]$. Admittedly, the two most popular and widely used formats today are the various navigation and path finding applications and the virtual globes, e.g. Google Earth.

While cartography deals with the methodical depiction of a geographical area (typically on a flat surface, called a chart or atlas) and communication of facts pertaining to this area (political, cultural, ecological etc.), geography builds upon it to "explore the areal differentiation in composition and structure on earth's surface" [55] and "study the relationships between people and their environments". In contrast to cartography's digital journey however, Geography as a subject in education has remained rather stagnant. Surely, the depiction of studied regions has changed significantly with the infusion of satellite images and high definition photographs, lending to the pupils' introduction to more realistic, accurate and believable contact to the landscape and its geopolitical features. Still, however, the way Geography is taught continues to revolve greatly around reading and memorizing names on a flat atlas - no matter how pretty or detailed the latter is. In order to bolster the development of geospatial literacy, Geography needs to take the leap into the digital, three-dimensional era. Why hold back on the inclusion of Geospatial Technology (GST) in the classroom when students today are more than comfortable with using virtual globes and finding the best route to their destination via navigation applets? Wouldn't it make sense to expect students not only welcome such a change but also help them gain a deeper, more concrete and more immersive grasp of the portrayed region's systems and the interconnections between them, making them more skilled, in the long run, in making informed and educated decisions about a place and its needs?

There are additional rewards to using GST as the stepping stone to teaching other disciplines. With Geography being a 'down to earth' discipline, both literally and figuratively, we can mine facts and data that pertain to actual events, systems and socio-economical phenomena of existing places. These data can then be processed with the help of Statistics and presented in the classroom using ICT media. The visualization of statistical data through the combined use of geospatial backgrounds and multimedia presentation (virtual globes, GST software, interactive boards etc.) constitutes a comprehensible way of presenting them to the average user in an effort to help the latter better understand and utilize them in their decision making efforts [56]. Taking under consideration the increased demand of many taught courses (e.g. history, geography, environmental training) for cartographic backgrounds [56], we are led to the reasonable conclusion that geospatial systems can play an important part in formulating the manner in which these courses are taught. 


\subsection{ICT and Education}

The development of ICT has supplied us with means to improve on various areas of our daily lives. Hand in hand with the benefits of living in the Information Society however walk exponentially increased demands - in knowledge, equipment, attitudes and assessment. It has become more than obvious that 21 st century students shall have to master skills which will enable them to meet these increased demands without the fear of making grievous mistakes [21]. School education can contribute towards achieving this goal and the adoption of ICT during the teaching process could help significantly [27]. It has been observed that the employment of ICT develops a dynamic environment in which data can reveal the meaning they convey in an efficient way, as well as show the correlations that exist between these and the real world [57, 51]. Thus, as students work with real life data with the aid of digital tools, they develop the knowledge and skillset necessary to evaluate, code and visualize these data in order to interpret and understand the derived information, developing their both their critical thinking and digital literacy in the process. It is a very straightforward conclusion then that the education system should be reformed in such a way that ICT is included in all activities $[58,13]$.

There is an "urban legend" according to which, modern students are 'digital natives' due to them being born in the age of Information Society and using various aspects of ICT on a daily basis. While both facts are undeniably true, they are not enough to qualify them as digitally literate [59, 21]. Many modern students are found lacking the digital skills required in their adult life [21]. At the same time teachers seem to be hindered by a slightly different challenge. In their classrooms they make merely procedural use of ICT, seemingly lacking the confidence to employ continuous and contemporary use [58]. Research has shown that they are plagued by many difficulties regarding its use during teaching process $[48,5]$. Part of the problem seems to be that, according to a report by the European Commission (2013) [21], it is not mandatory for them to be educated in the pedagogical use of ICT. This makes their transition from the traditional teaching model into a new, modern one where the ICT is used as the basic tool, appear to them a very intimidating and demanding undergoing.

We have already established that employing data drawn from actual places and events help students gain a better understanding of the information inferred by processing these. Furthermore, we expressed our claim that using GST and other ICT means for visually representing the processed data further boosts students' grasp of the taught material. Let us revisit then the questions posed earlier, regarding the reasons behind the slow, if any, infusion of GST elements in the classrooms. One of the most common ones seems to be hardware related, i.e. lack of necessary equipment and/or specialized personnel to install and maintain it. Many developing countries do not provide contemporary, fully equipped computer labs or interactive whiteboards, projectors and the like to facilitate ICT use in the classrooms $[60,58]$. To make things worse, in some of these countries there are schools or even institutions deprived of internet access; this prohibits their students from using modern day facilities built around cloud computing and mobile learning. Additionally, software complexity also seems to be causing issues in some cases, as it adds to the time required for training on the educators' part [61]. Moreover, there appears to be a consensus that the time required to organize and perform such 'technologyenhanced' teaching scenarios outweighs the benefits, thus adding to the teachers' reservations and even bias. Research however shows that, the higher the level of ICT training they have received the less reluctant they are to adopt such methods.

In order to bridge the space between education, demands of industry and requirements of everyday life, contemporary curriculums must be reformed and teachers ought to come to trust the use of technology. They will have to use the digital tools (e.g., radio, TV, internet, social media) if they truly hope to make their lessons have an impact on students and give them the 
motivation they need for learning. Not only they will have to provide but also to correctly employ the information presentation resources mentioned above. Accordingly, the same principle applies to the students [5], in their own respect.

\subsection{Visual Literacy, Graphic Literacy and Geospatial Literacy}

User perception varies according to personality, attribute traits, interests, personal experiences, etc. leading to different ways one perceives and processes the volume of information at hand. Visual literacy has grown into a social phenomenon as it can potentially influence decision making; above all else, an individual can have an active involvement in the process and take up commitments which they would normally hesitate to undertake. Ideas and meanings are inferred, correlations are made clear and forms and applications are grasped more firmly, as nearly everything can now be converted in sets of images [57]. Visual literacy is hence defined as the skill to not only read, interpret and assimilate optical shapes that pertain to visual communication [62], but also to critically valuate, create visual concepts and produce visual messages [19].

The multi-disciplinarity of visual literacy [102] is a valuable aid in the issue of assessing statistical information and constructing data visualizations [103]. Statistics employs tables, graphs and maps to organize, analyse and interpret data and their correlations [47]. Despite the fact that it (Statistics) has been incorporated into the Curriculum of formal education, a percentage of pupils and students still find it difficult to understand and make use of information when presented in either of those formats [31,65]. Hence we can argue that a main factor when it comes to translating data is the way in which they are visualized [40]. When optical literacy interacts with critical thinking, it prepares the student to identify misleading data and interpret them correctly instead. In bibliography it is mentioned that three stages of comprehension (elementary, intermediate and advanced) must be activated for the students to master optical literacy; these range from locating and reading the data (from a chart, for instance) to reading "beyond the data to integrate and interpret trends" [19].

Data visualization (in the shape of graphics, graphs, maps, etc.) appears as part of many aspects of everyday life e.g., news, education, work, etc. As such, it is also a multi-layered instrument, consisting or conveying varying details of information, depending on the reason behind its creation [66, 67]. The skill of data visualization and comprehension has become as important as learning how to read and write. Thus, we are referring to it as one more type of literacy [67]. Over the course of the recent years there have been various definitions of graphic literacy [68, 69, 70]. Everyone though tends to agree that it is related to the person's ability to read data, comprehend the relations that connect them and interpret them correctly by choosing the right type of graph [71].

In a typical educational system, students are being taught numerous methods of visualization (e.g. line charts, column charts, pie charts, spreadsheets, maps), yet they still face some difficulties when it comes to grasping their intended use and interpretation [66, 19, 57, 71, 72]. It has been discovered that the ability to interpret the connection between chart and graph demands mathematical reasoning [65]. Graphs are used by educators not only to check the mathematical and/or scientific knowledge of students but also their reading literacy. Thus, the latter must possess basic mathematical knowledge so they will be able to develop satisfactorily the skills regarding reading and rightly comprehending a graph [71]. It is a crucial tool concerning the organization, presentation and interpretation of information and statistical data [23] as well as an essential part of statistical literacy [46]. As it is related to how a person comprehends the data locally, nationally, and internationally [73], the pedagogical approach according to which the students will learn to use and interpret graphs also must be determining [74]. 
Geospatial technologies (GSTs), are used extensively in social sciences (economics, humanitarian studies, archaeology, geography, etc.) as well as in contemporary educational systems [75, 76] since they feature both high development rate and diffusion [76]. When it comes to visual representation and spatial analysis, assets like GIS, GPS, Remote Sensing, cartography, etc. are broadly employed $[77,78,79,80]$. They make use of social sciences like geography as a framework [81] to contribute to enhancing student skills in new, innovative ways - by bolstering attitudes and behaviours associated with the ability to learn $[82,83]$, while at the same time lead to the development of spatial thinking and reasoning $[84,85,86]$.

As we can see from the above, the interaction and interconnection between statistical and geospatial data in real time, leads to the development of the students' visual and geospatial cognition, as it piques their interest and focus in a very creative manner. So it's not wrong to talk about geospatial literacy -a term which includes both visual and graphic literacy [10].

\subsection{Web applications and teaching scenarios}

We established that there is an insurmountable need for citizens to not be passive towards the overwhelming data that is presented to them daily but rather be capable of using the data, comprehend and interpret them [28]. As an early vehicle for this goal, we need to create classroom activities which are based in realistic data (primary or secondary), originating from everyday life. Students shall have to be able to ask the right questions, use the appropriate graphs and tools for statistical analysis of data and to interpret the results with correct judgment [12]. STEM activities (Science, Technology, Engineering and Math) offer many opportunities for the students to get involved actively in the classroom. Mathematics and Statistics especially, often act as catalysts in such activities. Getting involved with STEM activities can aid in the development of students' statistical literacy to reach beyond the stage of calculations and formulas and transform into knowledge and critical thinking [37].

Teachers should have developed their digital skills to the extent that they will be able to embody them in the teaching process via various ways such as the creation of scenarios, worksheets, the use of digital tools in the classroom, etc. [21]. The use of PCs and the internet are means of communication with which the efficiency and effectiveness of activities in classroom can be improved. Students are encouraged to use ICT in a natural and sustainable way [58]. The visualization of data is a key part of the educational system and teachers with the necessary qualifications are needed, to lead/assist the students in the development of metacognitive skills [19]. Statistics allow for interdisciplinary approach [50] and since many students do not believe that statistics have anything to offer them, teachers will have to use examples based on realistic data (e.g., population by country, population migration, number of internet users per region, etc.) and social phenomena $[13,87]$.

The sharing and reuse of digital resources (statistical tools, worksheets such as Microsoft Excel (MS Excel), educational applications such as CODAP and I-USE web-based platforms, data repositories, applications such as Messenger, etc.) can be considered a useful educational tool for the creation of educational scenarios $[88,89,27,90,32]$. The cognitive style of students varies, and it is admissible that it can affect the acquisition of statistical literacy [34]. Teachers should aim at the interdisciplinary approach and innovation by adapting ICT to the creation of educational scenarios and activities.

The teaching scenarios should aim at the active participation of students [91], so as teachers we will have to manage properly the language for the meanings of teaching scenarios used in class to be understandable [43]. It is very important to pay additional attention to the structure of teaching scenarios and activities, so the mild skills of students improve (e.g., communication, 
collaboration, empathy, creativity, anger management, etc.). It is imperative for the teaching scenarios to be related to topics based in the students' everyday life inside and out of the school environment.

At the same time, it must be kept in mind the difficulty students face regarding the use, comprehension, and interpretation of various types of graphs or maps depending on the requested worksheet every time [46]. The theory of multimedia helps the reader to decrease the cognitive load while they set priorities in how they will handle the material they are given [92]. With the students actively participating in the cycle of Statistics, they will be able to correctly comprehend the causes of situation while they will develop the statistical, geospatial, and digital literacy of theirs.

\section{THE SitUATION IN GREECE}

The teaching of Statistics, from its first appearance in the Greek educational system until shortly before the end of the first decade of the 21 st century, was treated throughout its life as the fifth wheel. To get a better understanding of the problem, we consider it important to give a brief analysis of the prevailing philosophy and situation in the Greek educational system.

It first appeared in the Curriculum of the Primary School in 1969, as a simple reference [93]. Subsequently, for the next forty years or so, Statistics remained on the side-lines without playing the catalytic role for which it was intended. It exists as an entry in the Curricula [94] but its teaching is often skipped or, when done it is plagued by sloppiness and vague purposes and goals.

At the beginning of the 21st century, serious efforts were made for the reform of the Curriculum and the integration of Statistics as an original thematic unit in the wider area of Mathematics for the Gymnasium and the Lyceum, while also introducing it in other cognitive subjects as proof of its interdisciplinarity [95]. For the last two decades it has been included in the course of Stochastic Mathematics (Statistics and Probability) in compulsory education [96] while it is being taught in the Lyceum during the course of Probabilities [97, 98].

From the aforementioned review it becomes clear that originally the teaching of Statistics as a subject in compulsory education failed. This was due to poor implementation, since in the majority of cases it was not even taught at all, while in the few exceptional situations or schools that it was, teaching was incomplete and fragmentary. As a rule, it was always left for the end of the teaching period since its difficult concepts and plethora of terms were equally difficult for teachers and students to comprehend and interpret. Today, however, things have changed, as Statistics find its rightful place in the Curriculum as well as among the educational community. We consider the words 'understand' and 'interpret' to be the basis for Statistics which requires a proper reference framework to achieve a rational management of its data. This is what Geography brings into play with the help of ICT, as the use of maps and geospatial information provide a better perceived representation of real-world data. Additionally, the increasing rate at which Greek schools today are equipped with multimedia labs, interactive boards and projectors also facilitates the teaching of various subjects through STEM activities.

However, while there are a couple of teaching scenarios depositories available to Greek educators, no tools exist to help them represent statistical data in any form other than the traditional graphs, pies etc. (e.g. Excel Charts or Libre Office Calc). For our purposes, we needed a tool -online, preferably- which would enable teachers to visualize statistical data in the classroom in a way that would assist students identify and directly grasp their connection to reallife facts about a certain geographical region. We found the platform i-use (http://www.i-use.eu) to be very close to what we were aiming for in terms of visualization, with its option to 
superimpose the displayed Statistical values on the world map (i.e. data pertained to entire countries). Nevertheless, this did not fit our goals as our need was for the geographical background of Greece and its various administrative sub-divisions (i.e. Prefectures and Municipalities).

\subsection{Web platform and teaching scenarios}

The online platform Statistics4School (http://statistics4school.eu) was created to serve the goals outlined above. It was developed from scratch, using exclusively Free Open Software (FOSS), as a tailor-made version of the way i-use handles the submitted statistical data. The aim is to be used by teachers and students alike, both inside and outside the classroom. The design is kept simple and clear, in order to facilitate a smooth and low learning curve for all users. It offers two discreet but interrelated functions:

a. the tools to visualize statistical datasets against the geospatial backdrop of Greece, at the top level of its administrative regions (Prefectures and Municipalities)

b. serves as a depository, allowing the hosting and sharing of ICT-teaching scenarios for the purposes of interdisciplinary teaching, as a pedagogical practice to combine Statistics with other learning subjects

Datasets may originate from any online database, like the Hellenic Statistical Authority (ELSTAT) or be suitably constructed by field measurements and surveys (e.g. questionnaires). Many file formats for the hosted scenarios are supported, such as xls, csv, txt, kml. Users are required to register and login prior to using any of the platform's features, for reasons of renown and security, while the material there is under the Creative Commons (CC) regime.

\subsection{ICT-teaching scenarios}

Moving away from the traditional teacher-centred way of education, the teacher shows their students the green light for them to explore their knowledge of the concepts above, constantly stimulating their interest in a creative way through ICT, as they move towards the completion of each of the activities in the scenario. Guided exploration-discovery has been chosen as the most appropriate method wherein students 'discover' knowledge gradually. Teamwork is used as an educational technique [99] with varying levels of skill distribution, employing discussion, visual and oral presentation of the results of their activities, and the use of ICT. Students become familiar with the collaborative learning method, where working together, communication and interacting with the group members is pivotal. When this is accompanied by self-action [100] it borrows to cultivating skills related to observation, processing and analysis of statistical data to draw conclusions. The use of ICT and the holistic approach of the subject lead to the development of critical thinking and the ability to search for and correlate data in a multimedia learning environment.

For my $\mathrm{PhD}$ purposes, teaching scenarios were created in the context of research and application of the digital platform in schools. They are fully augmented ICT - teaching scenarios with readymade statistical data, teaching walkthrough, activities-worksheets, . $\mathrm{kml}$ files as well as guidelines for how they can make use of all of these on the digital platform. They can be downloaded and freely used (CC) in class by both teachers and students, from http://statistics4school.eu. Five scenarios were created, one of which is presented in this paper. Another one was created by myself and three more by the undergraduate colleague Mrs Spitieri. The logistical infrastructure needed to complete the activities of the teaching scenario is the supervisory material of the textbook, the worksheet, the computer lab with internet connection, a video projector, the interactive whiteboard, a printer, and the https website https://statistics4school.eu/. 


\subsubsection{Scenario - "Knowing the Population of Greece in Numbers"}

The teaching scenario entitled "Knowing the Population of Greece" is addressed to students of the 8th grade in Junior High School, and is part of their course in Geology-Geography. It was designed with the purpose of being compatible with the goals of Curricula [95]. The web-based platform https://statistics4school.eu/ is employed in the classroom, as it offers a set of tools that can be used for the implementation of the scenario and its sharing.

The main goal is the familiarization of the students with the use of statistical data retrieved from the ELSTAT, pertaining to the distribution of the population across the regions of Greece. With the aid of Web 2.0 and Web 3.0 services, data are visualized with the ultimate purpose of exploring the factors that contribute to the increase or decrease of said population, as well to understand the consequences of immigration and low birth rate in certain region.

At the end of the course, students should be able to understand the definitions of the population and its density as well as to distinguish and justify the factors that affect their distribution in a region. Secondly, students will have become familiar with the use of simple statistical functions that appear in our daily lives without us realizing it (e.g. changes in consumer income, minimum admission base in Universities, average course grade, etc.), with data retrieved either from the 'classic' Media (TV, newspapers, etc.) or from Social Media (Facebook, Instagram, etc.). Last but not least, they should be able to visualize the statistical data with the help of graphs and the geospatial background of Greece to compare the results and draw conclusions.

Students are divided into heterogeneous groups of 3-4 individuals, and one computer is assigned to each group. The groups are made up in such a way that in each one there are students who are distinguished for their ease in the use of mathematical and geographical concepts, maps and ICT, and students who are struggling with these particular areas.

Through guidance, with detailed instructions given in the worksheet and a separate manual, students are asked to implement the activities described therein, with the ultimate goal of developing critical thinking and cultivating both their statistical and geographical literacy.

The teaching scenario is divided into four (4) teaching hours.

1st teaching hour: The students, through the implementation of the 1st activity, initially attempt to record what is meant by the terms 'Population', and 'Population Density' and then, with the help of the pictures and the text that is given, should this is deemed necessary, to reformulate or complete the definition of the aforementioned concepts and calculate the population density. The island of Lesvos is used as an example (Figure 4).

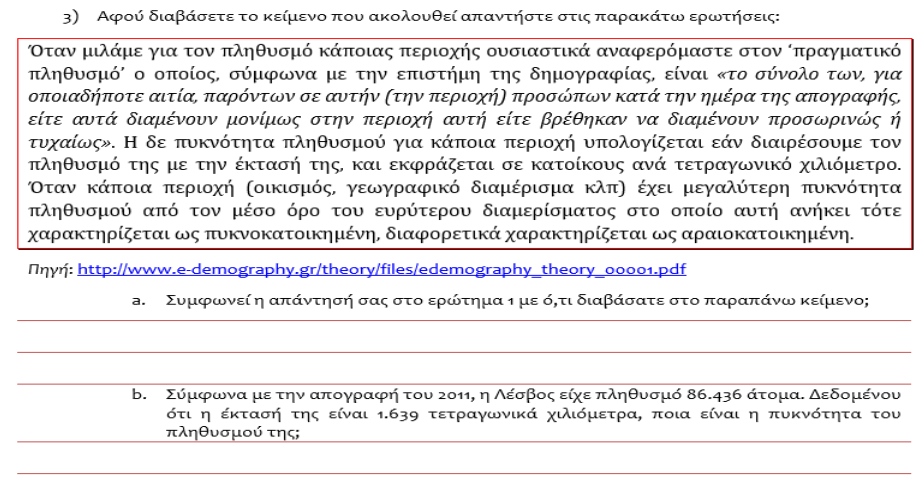

Figure 4: Question from $1^{\text {st }}$ activity 
2nd teaching hour: The content of the $2^{\text {nd }}$ activity aims students to identify the causes that contribute to the formation of the population distribution in Greece. The findings will be presented in the plenary of the class, in order to discuss and clarify - using examples - the factors that shape the population of Greece and its local distribution (Figure 5).

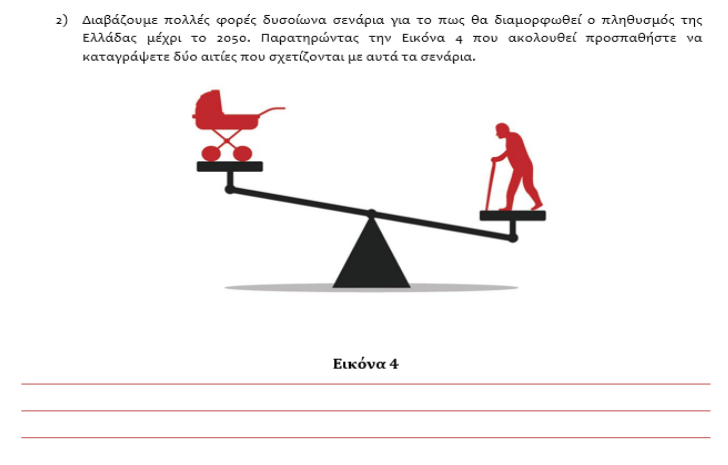

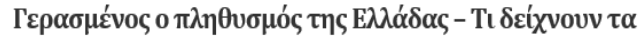

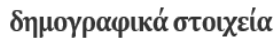

CNNGreece

02/07/2019

חnүń: cnn.gr - https://www.cnn.gr/news/ellada/story/182825/gerasmenos-0-plithysmos-tiselladas-ti-deixnoyn-ta-dimografika-stoixeia

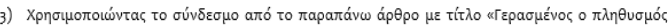

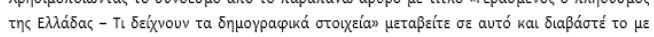

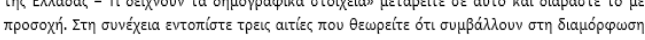

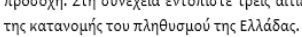

Figure 5: Questions from $2^{\text {nd }}$ activity

3rd teaching hour: In the next stage, again following the detailed instructions given in a separate sheet, they implement the 3rd and 4th activities by using the tools embedded in the web-based platform https://statistics4school.eu/. In these activities they will need to enter statistical data supplied to them (source: ELSTAT), concerning the distribution of the Population and the Population Density during the period 1991-2011, for the 13 Regions of Greece. Furthermore, they will study the changes in the values of these data, and evaluate them. The data need to be in a specific (and documented) format, in either .csv or .txt file, as follows:

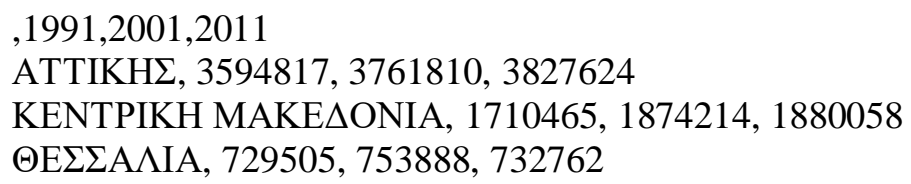

The comparison between the geospatial changes through time will be carried out via the tools of the web platform. These include:

a. simple statistic functions: Minimum-Maximum, Median, Standard Deviation, Sum, Percentage variation,

b. graphs: Column, Pie, Scatter, and

c. geospatial background of Greece, at the levels of Prefecture or Municipality, using a colour palette grading (Figure 6).

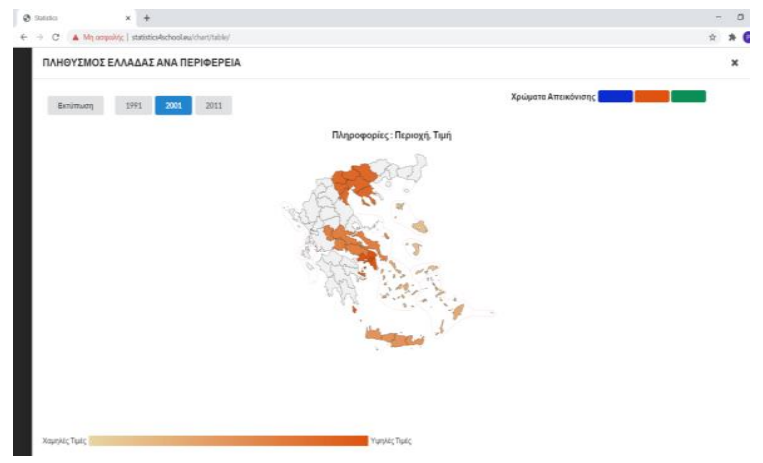

Figure 6. Geospatial background of Greece 
4th teaching hour: The last activity contains questions designed to test the achieved level of comprehension, as they are asked to predict the population of the 2021 census and indicate ways they believe can reverse the continuing decline of the population of Greece. Upon completion, the teacher will invite each group to submit to the plenary of the class the answers given by the students, with the ultimate goal to make them think creatively in order to make the connection between the topic of the worksheet and their daily life.

Four more teaching scenarios -related to Gross Domestic Product (GDP), tourism, livestock and energy- have been created and uploaded to the web platform, for sharing and reference. The platform may host worksheets, statistics files, geographical data shape files and scenarios, with the purpose to be used by teachers and students throughout the learning process to enhance concept clarification and cultivate multiple literacies.

\section{DisCUSSION}

Anyone, from the age of seven onwards, is typically considered to be 'literate' - i.e. knowing how to read and write. Education is a fundamental pillar in the evolutionary process of every society $[9,101]$ and literacy its largest building stone. Unfortunately, even today there are regions and/or countries with gaps in the provision of education to their citizens. Unemployment, nonexistent facilities for schools, etc. are some of the causes [9].

The wide spread of the Internet has led to the acquisition of such skills as digital literacy, media literacy, geospatial literacy, information literacy, etc. which very often overlap each other [33, 10]. Curiosity is the basis for the production of knowledge and people, like the multimodal beings constantly changing they are, incessantly search for opportunities to develop skills and behaviours to fit their daily lives. A person's education in Statistics provides the tools needed to reflect and therefore develop critical thinking [15] as decision making is based on the continuous evaluation of the data and arguments that arise from the case under consideration [102].

At the same time, the rapid advances and development of ICT requires the citizen to be able to choose the right information for decision making, having the critical ability to be able to discern the obstacles he may encounter [20]. The cultivation of critical thinking must be combined with the statistical education of the individual. Visualization of data (from graphs to maps) is necessary and useful as it will help to understand them, to reveal patterns that in any other case would go unnoticed while emphasizing the data themselves and their importance [103, 104, 71, $3]$.

Teachers play a catalytic role in the extent, if any, of their students' affection for Statistics and whether they will eventually come to comprehend the importance of statistical education. We consider that the collection, analysis, comprehension, interpretation and visualization of data, particularly of a problem that is directly related to students (e.g. career choice, university selection, use of statistical data at national or local level for various concepts) and their daily life can give them the opportunity to be actively involved in the learning process. This approach to knowledge, within the context of a modern learning environment while accompanied by the use of digital tools integrated in the context of the course, is best exercised through the exploratory method and collaborative teaching. In this fashion the student will develop multiple literacies with the main statistical literacy while the teacher will achieve the goals set in the Curriculum of each distinct course.

Students of all ages and levels of education take initiatives on issues related to viability and sustainability. Meanwhile, the educator, aiming at rising awareness and nurturing the new generation in modern perceptions, proves the point that it is imperative to adopt and apply 
modern learning theories for the development and cultivation of statistical, digital and visual literacy. We maintain that, the use of an ICT-based teaching scenario with the aid of a digital tool created entirely with FOSS, simple and friendly to students and teachers alike, is an innovative tool that steers in that direction.

We propose that through proper training of the educators, in ICT and Statistics, the methodical reform of the Curriculum of Geography, and provided that the existing technological impediments in the classrooms are overcome, Geography can become a very efficient medium through which other forms of literacy can be developed.

\section{ACKNOWLEDGEMENTS}

This research is self-funded.

\section{CONFLICT OF INTEREST}

The authors confirm there are no conflict of interest involve with any parties in this paper.

\section{REFERENCES}

[1] Muñiz-Rodríguez, L., Rodríguez-Muñiz, L. J. \& Alsina, A. (2020). Deficits in the Statistical and Probabilistic Literacy of Citizens: Effects in a World in Crisis. Mathematics 2020, 8, pp. 1-20.

[2] Hidayati, N. A., Waluya, S. B., Rochmad \& Wardono (2020). Statistics literacy: what, why and how? Journal of Physics: Conference Series,1613, Ahmad Dahlan International Conference on Mathematics and Mathematics Education 8-9 November 2019, Yogyakarta, Indonesia. doi:10.1088/1742-6596/1613/1/012080.

[3] Hood, J. C., Graber, C. \& Brase, G. L. (2020). Comparing the Efficacy of Static and Dynamic Graph Types in Communicating Complex Statistical Relationships. Frontiers in Psychology, 10, pp. 1-7. https://doi.org/10.3389/fpsyg.2019.02986.

[4] Johannssen, A., Chukhrova, N., Schmal, F. \& Stabenow, K. (2021). Statistical Literacy-Misuse of Statistics and Its Consequences. Journal of Statistics and Data Science Education, 00(0), pp. 1-9. https://doi.org/10.1080/10691898.2020.1860727.

[5] Rohita R. (2020). The Ability of Ece Teachers To Use ICT in The Industrial Revolution 4.0. Jurnal Obsesi: Jurnal Pendidikan Anak Usia Dini, 4(2), pp. 502-511. https://doi.org/10.31004/obsesi.v4i2.339.

[6] Elfitra \& Siregar, T. M. (2020). Statistical Literacy Analysis of Mathematics Education Students Through KKNI Assignments. Journal of Physics: Conference Series, 1462. The $6^{\text {th }}$ Annual International Seminar on Trends in Science and Science Education.

[7] Setiawan, E. P. (2020). Introducing statistical inference to senior high school students: a textbook analysis. $5^{\text {th }}$ Seminar Nasional Matematika dan Pendidikan Matematika (SENATIK) 2020. Journal of Physics: Conference Series, 1663, pp. 1-10. doi:10.1088/1742-6596/1663/1/012014.

[8] Rachmat, A. A. (2020). The Importance of Reading Literacy. Academic Writing Assignment. Retrived from, https://www.researchgate.net/publication/346384548_The_Importance_of_Reading_Literacy.

[9] Hande, R. D. (2020). A Geographical Analysis Of Literacy In Pune Administrative Division Of Maharashtra, India. Juni Khyat (UGC Care Group I Listed Journal), 10(5), pp. 91-100.

[10] Moorman L. (2019). The Evolution and Definition of Geospatial Literacy. In: Balram S., Boxall J. (eds) GIScience Teaching and Learning Perspectives. Advances in Geographic Information Science. Springer, Cham. https://doi.org/10.1007/978-3-030-06058-9_2.

[11] Pangrazio, L. \& Sefton-Green J. (2019). The social utility of 'data literacy'. Learning, Media and Technology, pp. 1-14. Routledge, Taylor \& Francis Group. https://doi.org/10.1080/17439884.2020.1707223.

[12] Frischemeier, D. (2020). Building statisticians at an early age-statistical projects exploring meaningful data in primary school. Statistics Education Research Journal, 19(1), pp. 39-56. 
[13] Rohayati, S., Agustini, A., \& Abdullah, A. A. (2020). Teaching an Undergraduate Statistics Class in Digital Era. Proceeding International Conference on Science and Engineering, 3, pp. 371-373.

[14] Risqi, E. N. \& Ekawati, R. (2020). How is the Statistical Literacy of Upper Secondary Students Based on Gender Differences? Jurnal Riset Pendidikan dan Inovasi Pembelajaran Matematika, 4(1), pp. 53-67.

[15] Grando, R. C. \& Lopes, C. E. (2020). Creative insubordination of teachers proposing statistics and probability problems to children. ZDM - Mathematics Education, 52, pp. 621-635. https://doi.org/10.1007/s11858-020-01166-6.

[16] Legaki, N. Z., \& Hamari, J. (2020). Gamification in statistics education: A literature review. In J. Koivisto, M. Buji, \& J. Hamari (Eds.), GamiFIN Conference 2020: Proceedings of the 4th International GamiFIN Conference, pp. 41-51.

[17] Rasmussen, E., Chawirah, T, Simon, M. \& Montiel, F. (2020). The use of hypothesis and critical thinking in statistics. Retrieved https://www.researchgate.net/publication/346009582_The_use_of_hypothesis_and_critical_thinking_ in_statistics.

[18] Campos, C. R. \& Perin A. P. (2020). About critical and behavioral competences in Statistics Education. Zetetiké, Campinas, SP, 2020, 28, pp. 1-18.

[19] Krejci, S. E., Ramroop-Butts, S., Torres, H. N. \& Isokpehi, R. D. (2020). Visual Literacy Intervention for Improving Undergraduate Student Critical Thinking of Global Sustainability Issues. Sustainability 2020, 12, pp. 1-19. doi:10.3390/su122310209.

[20] Pamungkas, A. S. \& Khaerunnisa, E. (2020). The analysis of student's statistical literacy based on prior knowledge and mathematical self esteem. Journal for the Mathematics Education and Teaching Practices, 1(1), pp. 43-51.

[21] Martín, S. C., González, M. C. \& García Peñalvo, F. J. (2019). Digital competence of early childhood education teachers: attitude, knowledge and use of ICT. European Journal of Teacher Education. pp. 1-15. Routledge, Taylor \& Francis Group. https://doi.org/10.1080/02619768.2019.1681393.

[22] Budgett, S. \& Rose, D. (2017). Developing statistical literacy in the final school year. Statistics Education Research Journal, 16(1), pp. 139-162.

[23] Souza, L. D., Lopes, C. E. \& Fitzallen, N. (2020). Creative Insubordination in Statistics Teaching Possibilities to Go Beyond Statistical Literacy. Statistics Education Research Journal, 19(1), pp. 7391.

[24] Muñoz D. E., Esparza, A. C. M., Ciprés, M. C. \& Muñoz Macías, M. G. (2020). Comprehension of statistical graphs and tables by primary school teachersin-training. Zetetiké, Campinas, SP, 2020, 28, pp. $1-25$.

[25] Fernadez-Chammoro, V., Pamplona, S. \& Perez-Fructuoso, M. J. (2020). Assessing prior knowledge of statistics in students attending an online university. Journal of Computing in Higher Education, 2020, 32, pp. 182-202.

[26] Zakari, I. S. (2020). Linking statistical literacy and data stewardship in Public Universities of Niger: Lessons learned from the collaboration with the national statistics institute. Statistical Journal of the IAOS, 36(S1), pp. 63-72. doi:10.3233/SJI-200708.

[27] Suhermi \& Widjajanti D. B. (2020). What are the roles of technology in improving student statistical literacy? Journal of Physics: Conference Series, 1581, pp. 1-19. doi:10.1088/17426596/1581/1/012067.

[28] Francois, K., Monteiro, C. \& Allo, P. (2020). Big-Data Literacy as a new vocation for Statistical Literacy. International Association for Statistical Education (IASE/ISI), Statistics Education Research Journal, 2020, 19 (1), pp. 194-205.

[29] Martin, E. R. (2014). What is Data Literacy? Journal of eScience Librarianship, 3(1), pp. 11-2. https://doi.org/10.7191/jeslib.2014.1069.

[30] Pothier, W. G. \& Condon, P. B. (2019). Towards data literacy competencies: Business students, workforce needs, and the role of the librarian. Journal of Business \& Finance Librarianship, 25(3-4), pp. 123-146. https://doi.org/10.1080/08963568.2019.1680189.

[31] Shreiner, T. L. \& Dykes, B. M. (2020). Visualizing the teaching of data visualizations in social studies: A study of teachers' data literacy practices, beliefs, and knowledge. Theory \& Research in Social Education, 49(2), pp. 262-306. doi: 10.1080/00933104.2020.1850382.

[32] Casey, S., Hudson, R., Harrison, T., Barker, H. \& Draper, J. (2020). Preservice teachers' design of technology-enhanced statistical tasks. Contemporary Issues in Technology and Teacher Education, 20(2), pp. 269-292. 
[33] Dolenc, K. \& Šorgo, A. (2020): Information literacy capabilities of lower secondary school students in Slovenia. The Journal of Educational Research, pp. 1-9. Routledge, Taylor \& Francis Group. https://doi.org/10.1080/00220671.2020.1825209.

[34] Masfigatin, T. \& Suprapto, E. (2020). Student's Statistical Literacy skills Based on the Reflective and Impulsive Cognitive Styles. Al-Jabar: Jurnal Pendidikan Matematika, 2020, 11(2), pp. 273-286.

[35] Hafiyusholeh, M., Budayasa, K. \& Siswono, T. Y. E. (2018). Statistical Literacy: High School Students in Reading, Interpreting and Presenting Data. Journal of Physics: Conference Series, 947. doi :10.1088/1742-6596/947/1/012036.

[36] Gal, I. (2019). Understanding statistical literacy: About knowledge of contexts and models. En J. M. Contreras, M. M. Gea, M. M. López-Martín y E. Molina-Portillo (Eds.), Actas del Tercer Congreso Internacional Virtual de Educación Estadística. Retrieved from www.ugr.es/local/fqm126/civeest.html.

[37] Hourigan, M. \& Leavy, A. M. (2020). Using integrated STEM as a stimulus to develop elementary students' statistical literacy. Teaching Statistics, 42, pp. 77-86. doi: 10.1111/test.12229.

[38] Perin, A. P., Campos, C. R. \& Lorenzetti-Wodewotzki, M. L. (2020). Contributions of Mathematical Modeling to the development of Statistical Literacy in students of a higher-level technological course. Brazilian Journal of Development, Curitiba, 2020, 6(6), pp. 32836-32852.

[39] Abdullah, A. A. (2017). Statistical Literacy For Beginner Voter. Proceedings of $1^{\text {st }}$ Ahmad Dahlan International Conference on Mathematics and Mathematics Education, Universitas Ahmad Dahlan, Yogyakarta, 13-14 October 2017, pp. 76-81.

[40] Aksoy, E. C. \& Bostan, M. I. (2021). Seventh Graders' Statistical Literacy an Investigation on Bar and Line Graphs. International Journal of Science and Mathematics Education, 19, pp. 397-418. https://doi.org/10.1007/s10763-020-10052-2.

[41] Engel, J. (2019). Statistical literacy and society: What is civic statistics? Stochastik in der Schule, 39(1), pp. 2-12. En J. M. Contreras, M. M. Gea, M. M. López-Martín y E. Molina-Portillo (Eds.), Actas del Tercer Congreso Internacional Virtual de Educación Estadística.

[42] Fernandez, M. S., Pomilio, C., Cueto, G., Filloy, J., Gonzalez-Arzac, A. Lois-Milevicich, J. \& Perez, A. (2020). Improving skills to teach statistics in secondary school through activity-based workshops. Statistics Education Research Journal, 19(1), pp. 106-119.

[43] Pip, A. \& Franklin, C. (2021): What Makes a Good Statistical Question? Journal of Statistics and Data Science Education, 29(1), pp. 122-130. https://doi.org/10.1080/26939169.2021.1877582.

[44] Voskoglou, M. Gr. \& Athanassopoulos, E. (2020). Statistical Thinking in Problem Solving. American Journal of Educational Research, 8(10), pp. 754-761. doi: 10.12691/education-8-10-3.

[45] Setianingsih, R. \& Rahmah D. A. (2020). Statistical reasoning levels of high school students in solving statistics related problems. Journal of Physics: Conference Series, 1569, International Conference on Science and Technology 2019. doi:10.1088/1742-6596/1569/4/042064.

[46] Arteaga, P., Díaz-Levicoy, D. \& Batanero, C. (2020). Chilean Primary School Children's Understanding of Statistical Graphs. Acta Scientiae (Canoas), 2020, 22(5), pp. 2-24.

[47] Nahdi, D. S., Jatisunda, M. G., Cahyaningsih, U., Kurino, Y. D., Juliar, E., \& Bilda, W. (2021). Statistical Literacy Analysis of Pre-Service Elementary Teachers Education. Proceedings of the $1^{\text {st }}$ Paris Van Java International Seminar on Computer, Science, Engineering, and Technology (PVJ_ISComSET), Tasikmalaya, Indonesia, July 15-16 2020, Journal of Physics: Conference Series, 1764.

[48] Rizou, O., \& Klonari, A. (2019). Using Web 2.0 Tools in Teaching Spatial Statistics: Secondary Teachers' Views From Greece. In Smart Geography, 100 Years of the Bulgarian Geographical Society, Nedkov, S., Zelezov, G., Ilieva, N., Nikolova, M., Koulov, B., Naydemov, K., Dimitrov, S. Eds.; Springer: Switzerland, pp. 55-63. https://doi.org/10.1007/978-3-030-28191-5_5.

[49] Hassan, A., Ghaffar, A. \& Zaman, A. (2020). An Investigative Study on University Students' Statistical Literacy in Pakistan. Sir Syed Journal of Education \& Social Research,3(1), pp. 159-165. https://doi.org/10.36902/sjesr-vol3-iss1-2020(159-164).

[50] Cazorla, I. M., Utsumi, M. C. \& Santana E. (2020). Statistics performance of elementary and middle school students in the context of D-Estat. Zetetiké, Campinas, SP, 2020, 28, pp. 1-25.

[51] Obrial, J. T. \& Caramoan-Lapinid, M. R. (2020). The Use of Statistical Investigation in Assessing Students' Performance in Statistics. Action Research and Innovation in Science Education, 2020, 3(2), pp. 47-54.

[52] Kadijevich, D. M. \& Stephens, M. (2020). Modern Statistical Literacy, Data Science, Dashboards and Automated Analytics and its Applications. The Teaching of Mathematics, 2020, XXIII(1), pp. 71-80. 
[53] Callingham, R. \& Watson, J. M. (2017). The development of statistical literacy at school. Statistics Education Research Journal, 16(1), pp. 181-201.

[54] Robinson, A. C., Demšar, U., Moore, A. B., Buckley, A., Jiang, B., Field, K., Kraak, M. J., Camboim, S. P. \& Sluter, C. R. (2017). Geospatial big data and cartography: research challenges and opportunities for making maps that matter. International Journal of Cartography, 3:sup1, pp. 32-60, https://doi.org/10.1080/23729333.2016.1278151

[55] Su-fen, L. (1984). The relation between Geography and Cartography. China Academic Journal Electronic Publishing House, 39(3), pp. 315-320, https://doi.org/10.11821/xb198403022

[56] Klonari, A., Mandrikas, A., Melista, A., Tzoura, M. (2014). One year pilot implementation of the new Greek geography curriculum in primary education. European Journal of Geography, 5(1), pp. 81-97.

[57] Kennedy H. \& Engebretsen, M. (2020). Introduction: The relationships between graphs, charts, maps and meanings, feelings, engagements. In Engebretsen, M. and H. Kennedy (Eds.), Data Visualization in Society. Amsterdam: Amsterdam University Press. doi:10.5117/9789463722902_ch01.

[58] Mahdum, M. Hadriana, H, \& Safriyanti, M. (2019). Exploring teacher perceptions and motivations to ICT use in learning activities in Indonesia. Journal of Information Technology Education: Research, 18, pp. 293-317. https://doi.org/10.28945/4366.

[59] Akçayır, M., Dündar, H. \& Akçayır, G. (2016). What makes you a digital native? Is it enough to be born after 1980? Computers in Human Behavior, 60, pp. 435440. https://doi.org/10.1016/j.chb.2016.02.089.

[60] Kweka, K. H. \& Ndibalema, P. (2018). Constraints Hindering Adoption of ICT in Government Secondary Schools in Tanzania: The Case of Hanang District. International Journal of Educational Technology and Learning, 4(2), pp. 46-57. doi:10.20448/2003.42.46.57.

[61] Kerski, J. J. (2003). The Implementation and Effectiveness of Geographic Information Systems Technology and Methods in Secondary Education. Journal of Geography, 102(3), pp. 128-137. https://doi.org/10.1080/00221340308978534

[62] Kress, G. \& Van Leeuwen, T. (2001). Multimodal discourse: The modes and media of contemporary communication. London: Arnold.

[63] Brumberger, E. (2019). Past, present, future: mapping the research in visual literacy. Journal of Visual Literacy, 38(3), pp. 165-180. https://doi.org/10.1080/1051144X.2019.1575043

[64] Börner, K., Bueckle, A., \& Gindaa, M. (2019). Data visualization literacy: Definitions, conceptual frameworks, exercises, and assessments. Proceedings of the National Academy of Sciences of the United States of America, 116(6), pp. 1857-1864. https://doi.org/10.1073/pnas. 1807180116

[65] Ozmen, Z. M., Guven, B. \& Kurak, Y. (2020). Determining the Graphical Literacy Levels of the $8^{\text {th }}$ Grade Students. Eurasian Journal of Educational Research, 86, pp. 269-292. doi:10.14689/ejer.2020.86.13.

[66] Engebretsen, M. (2020). From decoding a graph to processing a multimodal message: Interacting with data visualization in the news media. Nordicom Review, 4l(1), pp. 33-50. https://doi.org/10.2478/nor-2020-0004.

[67] Donohoe, D. \& Costello, E. (2020). Data Visualization Literacy in Higher Education: An Exploratory Study of Understanding of a Learning Dashboard Tool. International Journal of Emerging Technologies in Learning, 15(17), pp. 116-125. https://doi.org/10.3991/ijet.v15i17.15041

[68] Fry, E. (1981). Graphical literacy. Journal of Reading, 24(5), pp. 383-389.

[69] Friel, S. N., \& Bright, G. W. (1995). Graph knowledge: Understanding how students interpret data using graphs. (ERIC Document No: 391 661). Annual Meeting of the North American Chapter of the International Group for the Psychology of Mathematics Education, Columbus, Ohio.

[70] Zhang, J., Gan, Y., Scardamalia, M. \& Hong, H.Y. (2010). Early development of graphical literacy through knowledge building. Canadian Journal of Learning and Technology, 36(1).

[71] Bursal, M. \& Yetiş, S. (2020). Middle school students' graph skills and affective states about graphs. International Journal of Research in Education and Science, 6(4), pp. 692-704.

[72] Skrabankova, J. Popelka, S. \& Beitlova, M. (2020). Students' ability to work with graphs in physics studies related to three typical groups. Journal of Baltic Science Education, 19(2), pp. 298-316. https://doi.org/10.33225/jbse/20.19.298.

[73] Delport, D. H. (2021). Teaching first-year statistics students with COVID-19 real-world data: Graphs. Teaching Statistics, 43(1), pp. 36-43. https://doi.org/10.1111/test.12245.

[74] Gonçalves de Souza, J. M. \& Ferreira Monteiro, C. E. (2020). Understandings about graphs by field school teachers. Zetetiké, Campinas, SP, 2020, 28, pp. 1-19. 
[75] Buitrago, M. S. (2020). La tecnologia geoespacial como estrategia de pensamiento sistemico en la ingenieria. Encuentro Internacional de Educacion en Ingenieria ACOFI (EIEI 2020), La formacion de ingenieros: Un compromise para el desarrollo y la sostenibilidad, 15-18 de Septiembre 2020. Retrieved from https://acofipapers.org/index.php/eiei/article/view/782/787

[76] Bednarz, S. W., Acheson, G., \& Bednarz, R. S. (2006). Maps and Map Learning in Social Studies. Social Education, 70(7), pp. 398-404.

[77] Curtis, M. D. (2019). Professional Technologies in Schools: The Role of Pedagogical Knowledge in Teaching With Geospatial Technologies. Journal of Geography, 118(3), pp. 130-142. https://doi.org/10.1080/00221341.2018.1544267

[78] Pun-Cheng, L. S. C. (2001). Knowing our customers: A quantitative analysis of geomatics students. International Research in Geographical and Environmental Education, 10(3), pp. 322-341, ISSN 1038-2046 https://doi.org/10.1080/10382040108667448

[79] Satapathy, D. R., Katpatal, Y. B., \& Wate, S. R. (2008). Application of geospatial technologies for environmental impact assessment: an Indian Scenario. International Journal of Remote Sensing, 29(2), pp. 355-386. https://doi.org/10.1080/01431160701269002

[80] Aina, Y. A. (2012). Applications of Geospatial Technologies for Practitioners: An Emerging Perspective of Geospatial Education. In S. Jahan Miah (Eds.), Emerging Informatics - Innovative Concepts and Applications. Intech Open. ISBN: 978-953-51-0514-5

[81] Jo, J., \& Bednarz, S. W. (2014). Developing pre-service teachers' pedagogical content knowledge for teaching spatial thinking through geography. Journal of Geography in Higher Education, 38(2), pp. 301-3013. https://doi.org/10.1080/03098265.2014.911828

[82] Milson, A. J., \& Curtis, M. D. (2009). Spatial Visualization and Analysis with GIS in High School Geography. Retrieved https://proceedings.esri.com/library/userconf/educ09/educ/papers/pap_1093.pdf

[83] Demirci, A., Karaburun, A., \& Unlu, M. (2013). Implementation and effectiveness of GIS- based projects in secondary schools. Journal of Geography, 112(5), pp. 214-228. https://doi.org/10.1080/00221341.2013.770545

[84] Gryl, I., \& Jekel, T. (2012). Re-centring geoinformation in secondary education: Toward a spatial citizenship approach. Cartographica: The International Journal for Geographic Information and Geovisualization, 47(1), pp. 18-28. http://dx.doi.org/10.3138/carto.47.1.18

[85] Gold, A., Pendergast, P. M., Ormand, C. J., Budd, D. A., \& Mueller, K. J. (2018). Improving spatial thinking skills among undergraduate geology students through short online training exercises. International Journal of Science Education, 40(8), pp. 2205-2225. https://doi.org/10.1080/09500693.2018.1525621

[86] Klonari, A., \& Passadelli, S.A. (2019). Differences between dyslexic and non-dyslexic students in the performance of spatial and geographical thinking. Review of International Geographical Education Online, 9(2), pp. 284-303. https://doi.org/10.33403/rigeo.510360

[87] Panchenko, L. \& Khomiak, A. (2020). Education Statistics: Looking for a Case-study for Modelling. Retrived from, http://ceur-ws.org/Vol-2732/20200948.pdf.

[88] Pragnell, M. V., Roselli, T. \& Rossano, V. (2006). Can a Hypermedia Cooperative e-Learning Environment Stimulate Constructive Collaboration? Educational Technology \& Society, 9(2), pp. 119-132.

[89] Rizou, O., \& Klonari, A. (2016). Introducing 3D Visualization of Statistical Data in Education Using the i-Use Platform: Examples from Greece. Review of International Geographical Education Online, 6(3), pp. 253-270.

[90] Oliveira, S., Carvalho, L., Monteiro, C. \& Carvalho, C. (2020). Teachers dialoguing about statistical literacy with support of Messenger App for smartphones. In Proceedings of 16th International Conference Mobile Learning 2020, pp. 129-132.

[91] Hursen, C. \& Fasli, F. G. (2017). Investigating the Efficiency of Scenario Based Learning and Reflective Learning Approaches in Teacher Education. European Journal of Contemporary Education, 6(2), pp. 264-279.

[92] Chun, R. S. (2020). Giving Guidance to Graphs: Evaluating Annotations of Data Visualizations for the News. Visual Communication Quarterly, 27(2), pp. 84-97. doi:10.1080/15551393.2020.1749842.

[93] Michalis, I. (2006). The statistics curriculum in primary school and the conceptions - knowledge, comprehension - of students about graphical representations of data. Thesis, retrieved from https://www.didaktorika.gr/eadd/handle/10442/20053. DOI: 10.12681/eadd/20053 
International Journal of Education (IJE) Vol.9, No.4, December 2021

[94] Hatzistefanou, S. (2011). Empirical study of the capacity of developing statistical concepts by the students of the first and second class of Lyceum through the use of suitable training software. Thesis, retrieved from http://me.math.uoa.gr/dipl/dipl_Chatzistefanou\%20Sofia.pdf

[95] CROSS THEMATIC CURRICULUM FRAMEWORK FOR COMPULSORY EDUCATION (2003). Translated from the Official Gazette issue B, nr 303/13-03-03 and issue B, nr 304/13-03-03 by members of the P.I. From: http://www.pi-schools.gr/programs/depps/index_eng.php

[96] Pedagogical Institute P.I. (2011). Mathematics Curriculum for Compulsory Education-Gymnasium.

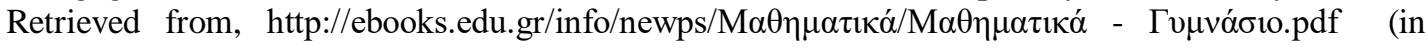
Greek)

[97] Official gazette 162/22-01-2015, Issue B. Mathematics Curricula for General Lyceum courses: "Mathematics" for A and B grades, for the elective group of Positive Studies B and C grades of and of General Lyceum and "Mathematics and Statistics" of C grade and for the elective group of Economics-Politics-Social and pedagogical Studies of General Lyceum, pp. 1937- 2161 (in Greek)

[98] Official gazette 3027/21-07-2020, Issue B. Mathematics Curricula for General Lyceum course "Mathematics and Statistics" of C grade, pp. 30771- 30790 (in Greek)

[99] Honomichi R. D. \& Chen, Z. (2012). The role of guidance in children's discovery learning. WIREs Cognitive Science, 3, pp. 615-622. doi:10.1002/wcs.1199

[100] Alfieri, L., Brooks, P. J., Aldrich, N. J. \& Tenenbaum, H. R. (2011). Journal of Educational Psychology, 103(1), pp. 1-18. DOI:10.1037/a0021017

[101]Lipic, N. \& Ovsenik, M. (2020). The Effect of Statistical Literacy on Response to Environmental Change. Organizacija, 53(2). pp. 147-163. doi:10.2478/orga-2020-0010.

[102] Pereira, F. A., Rodrigues, C. K. \& Souza, F. (2020). Research on variability in Statistical Education: a systematic review of literature. Zetetiké, Campinas, SP, 2020, 28, pp. 1-24.

[103]Akshay, N., Minces, V., Vazhayil, A., Gopalasamy, V. \& Bhavani, R. R. (2020). There's Data all around you: Improving data literacy in high schools through STEAM based activities. Fablean Asia 2020. Retrived from, https://par.nsf.gov/biblio/10166600-data-all-around-you-improving-dataliteracy-high-schools-through-steam-based-activities

[104] Vanderplas, S., Cook, D. \& Hofmann, H. (2020). Testing Statistical Charts: What Makes a Good Graph? The Annual Review of Statistics and Its Application, 7(13), pp. 1-28. 